\title{
Changes in extreme temperature indices over the Peripannonian region of Bosnia and Herzegovina
}

TATJANA POPOV, SLOBODAN GNJATO, GORAN TRBIĆ

University of Banja Luka, Faculty of Natural Sciences and Mathematics, Department of Geography, Banja Luka, Bosnia and Herzegovina; e-mail: tatjana.popov@pmf.unibl.org

ABSTRACT The paper analyzes changes in extreme temperature indices over the Peripannonian region of Bosnia and Herzegovina. Data on daily minimum and maximum temperatures during the period 1961-2016 from four meteorological stations were used for the calculation in the RClimDex (1.0) software trends in 16 indices recommended by the Expert team on climate change detection and indices. The estimated significant upward tendency in indices of warm extremes and downward in cold-related indices confirm that warming is present. The highest trend values were obtained for indices TXx, TNn, TN90p, TX90p, SU25, SU30 and WSDI. The results indicate significant distributional changes in the period 1987-2016 compared to the period 1961-1990. A significant positive (negative) correlation between the East-Atlantic pattern and indices of warm (cold) extremes was determined throughout the year. In winter and spring, significant links to the North Atlantic Oscillation and the Arctic Oscillation, respectively, were also found.

KEY WORDS extreme temperature indices - linear trend - statistical distribution - climate change - Peripannonian region (Bosnia and Herzegovina)

POPOV, T., GNJATO, S., TRBIĆ, G. (2019): Changes in extreme temperature indices over the Peripannonian region of Bosnia and Herzegovina. Geografie, 124, 1, 19-40.

Received November 2017, accepted February 2019.

(C) Česká geografická společnost, z. s., 2019 


\section{Introduction}

Unequivocal changes in various temperature characteristics - both mean temperatures and the extreme temperature events (its frequency, intensity and/or duration) were determined during the second half of the $20^{\text {th }}$ century and at the beginning of the $21^{\text {st }}$ century all over the world (IPCC 2014). Studies at different spatial scales determined trends in extreme temperature indices consistent with the warming. Global scale studies found upward trends in warm temperature extremes, whereas cold ones displayed a downward tendency (Alexander et al. 2006; Donat et al. 2013; Morak, Hegerl, Christidis 2013). Alexander et al. (2006) determined a significant decrease (increase) in the annual occurrence of cold (warm) nights and days over $70 \%$ of the global land area. The absolute temperature indices, i.e. the annual maximum and minimum values of daily maximum and minimum temperatures (TXX,TXn, TNx and TNn) displayed an upward tendency (Alexander et al. 2006, Donat et al. 2013). The length of growing season over most parts of the Northern Hemisphere mid-latitudes increased (Frich et al. 2002). The changes in the fixed threshold-based indices also confirm global warming. The annual occurrence of indices of cold temperature extremes such as frost days and ice days has decreased during the second half of the $20^{\text {th }}$ century, whereas conversely, the annual occurrence of indices of warm temperature extremes such as tropical nights and summer days showed even more prominent positive trends in vast majority of world regions (Alexander et al. 2006, Frich et al. 2002). The prominent and significant positive trends in the occurrence of warm spells were also recorded during this period, whereas duration of cold spells showed a downward tendency (Donat et al. 2013). Furthermore, distributions of both daily maximum and minimum temperatures significantly shifted towards higher values in the period 1981-2010 compared to the period 1951-1980 (Donat, Alexander 2012). During that period, the significant shifts in probability distributions of the extreme temperature indices were also found over the Northern Hemisphere midlatitudes associated with the warming (Alexander et al. 2006). These global tendencies - increase in warm temperature indices and decrease in cold ones - were confirmed by numerous regional and local studies all over the world (Caloiero 2017, Chen et al. 2015, Filahi et al. 2016, Peterson et al. 2008, Skansi et al. 2013, Wang et al. 2018).

Globally observed trends were confirmed in Europe at the continental scale (Andrade, Leite, Santos 2012; Chen et al. 2015; Klein Tank, Können 2003) and in different regions across the continent - over the Iberian Peninsula (Fonseca et al. 2016), Apennine Peninsula (Fioravanti, Piervitali, Desiato 2016), Balcan Peninsula (Kioutsioukis, Melas, Zerefos 2010), Alps (Brugnara et al. 2016). Positive trends in warm temperature indices and negative trends in cold ones over the Pannonian basin and its surrounding areas were previously determined by several regional 
scale studies (Bartholy, Pongrácz 2007; Lakatos et al. 2016), but also by numerous local scale studies which covered parts of this region (Branković et al. 2013; Croitoru, Piticar 2014; Graczyk et al. 2017; Nemec et al. 2013; Ruml et al. 2017).

In Bosnia and Herzegovina, studies determined positive trends in mean annual and seasonal temperatures (Trbić, Popov, Gnjato 2017). However, trends in temperature extremes have been previously poorly examined. Moreover, research on changes in the extreme temperature indices distributions has not been done so far. The main goal of this study was to analyze trends in temperature extremes using 16 indices recommended by the joint Citizens' Climate Lobby ( $\mathrm{CCl}$ ), Joint Technical Commission for Oceanography and Marine Meteorology (JCOMM) and World Climate Research Programme (WCRP) Expert Team on Climate Change Detection and Indices (ETCCDI) for the climate change assessment. Further, aim is to investigate changes in the selected indices distributions. Given the existing gap in the knowledge, this study aims to reveal novel information about the recent temperature extremes variability over this part of Peripannonian region.

\section{Study area}

The Peripannonian region of Bosnia and Herzegovina is a part of the large Pannonian macromorphological region of Central Europe (represents part of its southern rim). It is located in the northern part of Bosnia and Herzegovina at $43^{\circ} 57^{\prime} 22^{\prime \prime}-45^{\circ} 16^{\prime} 35^{\prime \prime} \mathrm{N}$ and $15^{\circ} 43^{\prime} 49^{\prime \prime}-19^{\circ} 37^{\prime} 25^{\prime \prime} \mathrm{E}$ (Fig. 1). It covers an area of $18,951 \mathrm{~km}^{2}$ ( $37 \%$ of the total Bosnia and Herzegovina territory). Study area encompass the lowland of the Sava River basin (and basins of its tributaries Una, Vrbas, Bosna and Drina) up to $200 \mathrm{~m}$ and the southern rim of the Pannonian Basin with hills and low ore and flysch mountains and horst mountains from $200 \mathrm{~m}$ to $800 \mathrm{~m}$ (in some locations up to $1,000 \mathrm{~m}$ ).

Western parts of the region are slightly cooler than the eastern. Average annual temperature ranges from $10.2{ }^{\circ} \mathrm{C}$ in the west to an $11.3^{\circ} \mathrm{C}$ in the extreme northeast (Trbić 2010). In the lowland area along the Sava River, annual precipitation decreases from $\sim 900 \mathrm{~mm}$ in the west to $700 \mathrm{~mm}$ in the east. Precipitation increases towards the mountainous rim areas in the south (1,000-1,200 mm; Trbić 2010). The primary precipitation maximum and minimum occur in June and October, respectively.

\section{Data and methods}

Changes in the extreme temperature indices over the Peripannonian region in Bosnia and Herzegovina during the period 1961-2016 were analyzed based on 


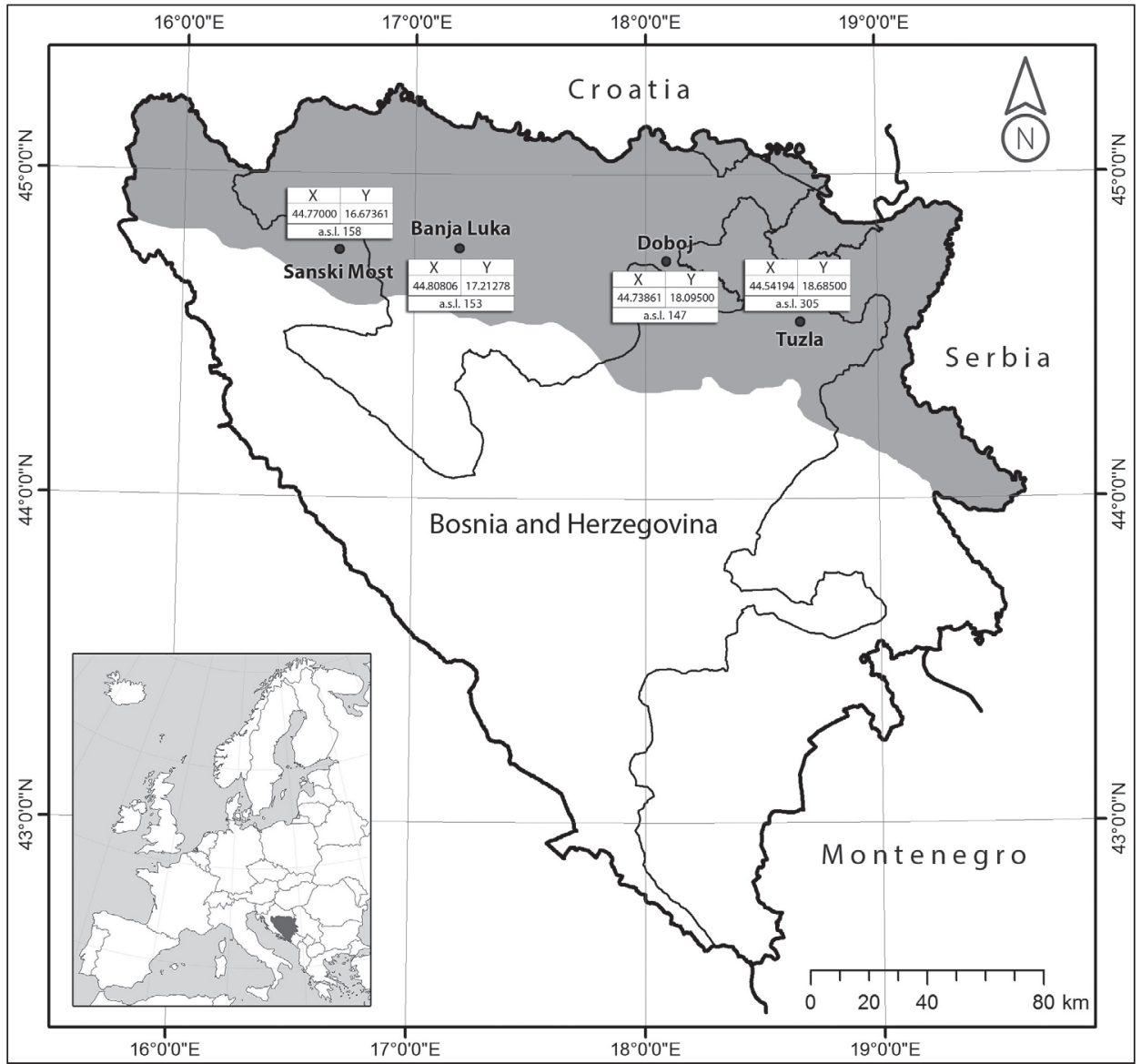

Fig. 1 - The geographical location of the study area with coordinates and elevations of the four meteorological stations used in the study

data sets of daily maximum air temperatures (Tmax) and daily minimum air temperatures (Tmin) from four meteorological stations located in different parts of the region: Sanski Most (SM), Banjaluka (BL), Doboj (DB) and Tuzla (TZ). The regional average time series (Region) of Tmax and Tmin were obtained as a mean of the daily maximum air temperatures and daily minimum air temperatures values for individual meteorological stations. Data were provided by the Federal Hydrometeorological Institute and the Republic Hydrometeorological Service of the Republic of Srpska. During the observed period, stations did not change their locations, but there were some short interruptions in measurements during the war period 1992-1996. Before trend calculations, basic data quality control procedure in RClimDex was performed. A few outliers (defined as values outside 
a range of four standard deviations of the climatological mean value for the day) were found and then checked and confirmed. The statistical parameters of the input variables time series are given in Table 1.

The average annual Tmax and Tmin in the Peripannonian region of Bosnia and Herzegovina are $17.0^{\circ} \mathrm{C}$ and $5.6^{\circ} \mathrm{C}$, respectively (Table 2). Summer is the warmest season $\left(27.0^{\circ} \mathrm{C}\right.$ and $13.6^{\circ} \mathrm{C}$, respectively), whereas winter being the coldest $\left(5.8^{\circ} \mathrm{C}\right.$ and $-2.7^{\circ} \mathrm{C}$, respectively). Tmax does not show the substantial differences in autumn and spring $\left(17.6^{\circ} \mathrm{C}\right.$ in both seasons), whereas for Tmin autumn is warmer than spring $\left(6.3^{\circ} \mathrm{C}\right.$ vs. $\left.5.1^{\circ} \mathrm{C}\right)$.

Table 1 - Statistical parameters of the input variables time series in the period 1961-2016

\begin{tabular}{|c|c|c|c|c|c|c|c|c|c|c|c|c|}
\hline \multirow[t]{2}{*}{ Station } & \multicolumn{2}{|c|}{$\begin{array}{c}\text { Mean } \\
\left({ }^{\circ} \mathrm{C}\right)\end{array}$} & \multicolumn{2}{|c|}{$\begin{array}{c}\text { Maximum } \\
\left({ }^{\circ} \mathrm{C}\right)\end{array}$} & \multicolumn{2}{|c|}{$\begin{array}{l}\text { Minimum } \\
\left({ }^{\circ} \mathrm{C}\right)\end{array}$} & \multicolumn{2}{|c|}{$\begin{array}{c}\text { Standard } \\
\text { deviation }\left({ }^{\circ} \mathrm{C}\right)\end{array}$} & \multicolumn{2}{|c|}{ Skewness } & \multicolumn{2}{|c|}{ Kurtosis } \\
\hline & Tmax & Tmin & Tmax & Tmin & Tmax & Tmin & Tmax & Tmin & Tmax & Tmin & Tmax & Tmin \\
\hline SM & 17.0 & 5.1 & 19.3 & 7.7 & 15.0 & 3.6 & 1.0 & 0.8 & 0.028 & 0.671 & -0.698 & 0.789 \\
\hline$B L$ & 17.3 & 5.8 & 19.9 & 8.5 & 15.1 & 4.3 & 1.3 & 1.0 & 0.176 & 0.601 & -0.944 & -0.313 \\
\hline DB & 17.0 & 6.1 & 19.1 & 8.2 & 15.0 & 4.9 & 1.1 & 0.7 & 0.367 & 0.400 & -0.745 & 0.130 \\
\hline TZ & 16.8 & 5.4 & 19.4 & 7.2 & 15.0 & 4.4 & 1.1 & 0.7 & 0.316 & 0.419 & -0.821 & -0.224 \\
\hline Region & 17.0 & 5.6 & 19.4 & 7.9 & 15.2 & 4.4 & 1.1 & 0.8 & 0.182 & 0.579 & -0.892 & 0.096 \\
\hline
\end{tabular}

Table 2 - Annual and seasonal mean values of the input variables in the period 1961-2016

\begin{tabular}{|c|c|c|c|c|c|c|c|c|c|c|}
\hline \multirow[t]{2}{*}{ Station } & \multicolumn{5}{|c|}{$\operatorname{Tmax}\left({ }^{\circ} \mathrm{C}\right)$} & \multicolumn{5}{|c|}{$\operatorname{Tmin}\left({ }^{\circ} \mathrm{C}\right)$} \\
\hline & Winter & Spring & Summer & Autumn & Year & Winter & Spring & Summer & Autumn & Year \\
\hline SM & 5.8 & 17.5 & 27.0 & 17.4 & 17.0 & -3.1 & 4.6 & 13.0 & 5.9 & 5.1 \\
\hline $\mathrm{BL}$ & 6.0 & 17.8 & 27.4 & 17.6 & 17.3 & -2.6 & 5.3 & 14.0 & 6.4 & 5.8 \\
\hline DB & 5.5 & 17.7 & 27.0 & 17.6 & 17.0 & -2.4 & 5.6 & 14.3 & 6.8 & 6.1 \\
\hline $\mathrm{TZ}$ & 5.7 & 17.2 & 26.5 & 17.5 & 16.8 & -2.8 & 5.0 & 13.2 & 6.0 & 5.4 \\
\hline Region & 5.8 & 17.6 & 27.0 & 17.6 & 17.0 & -2.7 & 5.1 & 13.6 & 6.3 & 5.6 \\
\hline
\end{tabular}

Table 3 - Decadal linear trends in the input variables in the period 1961-2016

\begin{tabular}{|c|c|c|c|c|c|c|c|c|c|c|}
\hline \multirow[t]{2}{*}{ Station } & \multicolumn{5}{|c|}{$\operatorname{Tmax}\left({ }^{\circ} \mathrm{C}\right)$} & \multicolumn{5}{|c|}{$\operatorname{Tmin}\left({ }^{\circ} \mathrm{C}\right)$} \\
\hline & Winter & Spring & Summer & Autumn & Year & Winter & Spring & Summer & Autumn & Year \\
\hline SM & $0.5^{\mathrm{b}}$ & $0.4^{\mathrm{b}}$ & $0.5^{\mathrm{a}}$ & 0.1 & $0.4^{\mathrm{a}}$ & $0.4^{\mathrm{b}}$ & $0.2^{b}$ & $0.4^{\mathrm{a}}$ & $0.2^{\mathrm{d}}$ & $0.3^{\mathrm{a}}$ \\
\hline$B L$ & $0.7^{b}$ & $0.5^{\mathrm{a}}$ & $0.7^{\mathrm{a}}$ & $0.3^{\mathrm{b}}$ & $0.6^{\mathrm{a}}$ & $0.6^{\mathrm{b}}$ & $0.4^{\mathrm{a}}$ & $0.6^{\mathrm{a}}$ & $0.4^{\mathrm{b}}$ & $0.5^{\mathrm{a}}$ \\
\hline $\mathrm{DB}$ & $0.7^{\mathrm{b}}$ & $0.5^{\mathrm{b}}$ & $0.5^{\mathrm{b}}$ & 0.3 & $0.4^{\mathrm{a}}$ & $0.5^{\mathrm{b}}$ & $0.2^{b}$ & $0.4^{\mathrm{a}}$ & 0.2 & $0.3^{\mathrm{a}}$ \\
\hline $\mathrm{TZ}$ & $0.5^{\mathrm{b}}$ & $0.5^{\mathrm{b}}$ & $0.5^{\mathrm{a}}$ & $0.3^{\mathrm{d}}$ & $0.5^{a}$ & $0.4^{\mathrm{b}}$ & $0.2^{b}$ & $0.4^{\mathrm{a}}$ & $0.2^{\mathrm{d}}$ & $0.3^{\mathrm{a}}$ \\
\hline Region & $0.6^{\mathrm{b}}$ & $0.5^{\mathrm{b}}$ & $0.6^{\mathrm{a}}$ & $0.3^{c}$ & $0.5^{\mathrm{a}}$ & $0.4^{\mathrm{b}}$ & $0.2^{\mathrm{b}}$ & $0.4^{\mathrm{a}}$ & $0.2^{c}$ & $0.3^{\mathrm{a}}$ \\
\hline
\end{tabular}

Confidence level at $99.9 \%\left({ }^{a}\right), 99 \%\left({ }^{b}\right), 95 \%\left({ }^{c}\right)$ and $90 \%\left(\left(^{d}\right)\right.$ 
Table 4 - Definitions of extreme temperature indices used in the study

\begin{tabular}{|c|c|c|c|}
\hline Index & Indicator name & Definition & Units \\
\hline TXx & $\begin{array}{l}\text { Maximum value of daily } \\
\text { maximum temperature }\end{array}$ & Annual maximum value of daily maximum temperature & ${ }^{\circ} \mathrm{C}$ \\
\hline TXn & $\begin{array}{l}\text { Minimum value of daily } \\
\text { maximum temperature }\end{array}$ & Annual minimum value of daily maximum temperature & ${ }^{\circ} \mathrm{C}$ \\
\hline TNx & $\begin{array}{l}\text { Maximum value of daily } \\
\text { minimum temperature }\end{array}$ & Annual maximum value of daily minimum temperature & ${ }^{\circ} \mathrm{C}$ \\
\hline TNn & $\begin{array}{l}\text { Minimum value of daily } \\
\text { minimum temperature }\end{array}$ & Annual minimum value of daily minimum temperature & ${ }^{\circ} \mathrm{C}$ \\
\hline TX10p & Cold days & Number of days when Tmax $<10^{\text {th }}$ percentile & days \\
\hline TX90p & Warm days & Number of days when Tmax $>90^{\text {th }}$ percentile & days \\
\hline TN10p & Cold nights & Number of days when Tmin $<10^{\text {th }}$ percentile & days \\
\hline TN90p & Warm nights & Number of days when Tmin $>90^{\text {th }}$ percentile & days \\
\hline ID0 & Number of icing days & Annual count of days when $\operatorname{Tmax}<0^{\circ} \mathrm{C}$ & days \\
\hline FD0 & Number of frost days & Annual count of days when $\operatorname{Tmin}<0^{\circ} \mathrm{C}$ & days \\
\hline SU25 & Number of summer days & Annual count of days when $\operatorname{Tmax}>25^{\circ} \mathrm{C}$ & days \\
\hline SU30 & Number of tropical days & Annual count of days when $\operatorname{Tmax}>30^{\circ} \mathrm{C}$ & days \\
\hline TR20 & Number of tropical nights & Annual count of days when $\operatorname{Tmin}>20^{\circ} \mathrm{C}$ & days \\
\hline WSDI & Warm spell duration index & $\begin{array}{l}\text { Annual count of days with at least } 6 \text { consecutive days when } \\
\text { Tmax }>90^{\text {th }} \text { percentile }\end{array}$ & days \\
\hline CSDI & Cold spell duration index & $\begin{array}{l}\text { Annual count of days with at least } 6 \text { consecutive days when } \\
\text { Tmin }<10^{\text {th }} \text { percentile }\end{array}$ & days \\
\hline GSL & Growing season length & $\begin{array}{l}\text { Annual ( } 1^{\text {st }} \text { Jan to } 31^{\text {st }} \text { Dec in Northern Hemisphere) count } \\
\text { between first span of at least } 6 \text { days with daily mean } \\
\text { temperature }>5^{\circ} \mathrm{C} \text { and first span after July } 1^{\text {st }} \text { of } 6 \text { days } \\
\text { with daily mean temperature }<5^{\circ} \mathrm{C}\end{array}$ & days \\
\hline
\end{tabular}

Source: ETCCDI 2009

During the observed period 1961-2016, both Tmax and Tmin showed significant upward trends, both annually and seasonally (only insignificant in some areas in autumn; Table 3). The annual Tmax and Tmin increased by $0.4^{\circ} \mathrm{C}-0.6^{\circ} \mathrm{C}$ per decade and $0.3^{\circ} \mathrm{C}-5^{\circ} \mathrm{C}$ per decade, respectively. Although increasing trend was apparent throughout the year, the warming was most prominent in summer $\left(0.5^{\circ} \mathrm{C}-0.7^{\circ} \mathrm{C}\right.$ per decade and $0.4^{\circ} \mathrm{C}-0.6^{\circ} \mathrm{C}$ per decade) and then in winter and spring.

A set of 16 extreme temperature indices recommended by the joint CCl/JCOMM/ WCRP Expert Team on Climate Change Detection and Indices (ETCCDI) for climate change assessment (Table 4) was chosen for the analysis of recent temperature extremes variability over the Peripannonian region.

The selected indices cover a few different extremes categories (Alexander et al. 2006):

- Absolute indices representing maximum or minimum value within a year (TXx, TXn, TNx and TNn). 
- Percentile-based indices defined as the number of days exceeding fixed percentile thresholds - in this study the $10^{\text {th }}$ and $90^{\text {th }}$ percentile were chosen, with the period 1961-1990 as a base period for determining its frequency (TX10p, TX90p, TN10p and TN90p).

- Fixed threshold-based indices defined as the number of days on which a temperature value falls above or below a fixed threshold (FD0, ID0, SU25, SU30 and TR20).

- Duration-based indices defined as periods of the excessive warmth and cold or in the case of growing season duration of mild periods (WSDI, CSDI and GSL).

Average annual values of extreme temperature indices used in the study are given in Table 5.

The extreme temperature indices were calculated using RClimDex (1.0) package (Zhang, Yang 2004). Trend estimate and its statistical significance were also computed in RClimDex by linear least square method (Zhang, Yang 2004). Trends were calculated by stations individually and for time series averaged for the whole Peripannonian region.

In order to further examine changes in extreme temperatures, changes in distributions of indices between the two sub-periods - the standard climatological period 1961-1990 and the period of the last thirty years 1987-2016 were analyzed. Two-tailed nonparametric Kolmogorov-Smirnov test was performed in XLSTAT Version 2014.5.03 to test whether the indices distributions were significantly different in two specified periods.

Basic correlation analysis of the links between the observed changes and the large-scale atmospheric circulation patterns over the Northern Hemisphere was performed. Data on the East-Atlantic (EA) pattern, the North Atlantic Oscillation

Table 5 - Average values of extreme temperature indices in the period 1961-2016

\begin{tabular}{lcccccccc}
\hline Index & TXx & TXn & TNx & TNn & TX10p & TX90p & TN10p & TN90p \\
\hline SM & 35.9 & -5.7 & 18.8 & -17.8 & 33.3 & 49.1 & 32.1 & 50.4 \\
BL & 36.9 & -5.5 & 20.1 & -16.1 & 31.5 & 53.7 & 30.5 & 58.2 \\
DB & 36.2 & -5.8 & 20.1 & -16.5 & 33.0 & 49.7 & 33.4 & 49.1 \\
TZ & 35.9 & -6.0 & 19.1 & -16.1 & 33.6 & 52.8 & 33.7 & 49.4 \\
Region & 36.1 & -5.4 & 19.0 & -16.2 & 32.6 & 51.4 & 32.8 & 52.7 \\
\hline Index & ID0 & FD0 & SU25 & SU30 & TR20 & WSDI & CSDI & GSL \\
\hline SM & 16.2 & 93.7 & 88.7 & 27.9 & 0.3 & 8.3 & 3.1 & 273.9 \\
BL & 16.1 & 87.8 & 93.3 & 32.7 & 1.3 & 11.9 & 3.2 & 277.8 \\
DB & 16.1 & 81.0 & 90.2 & 28.8 & 1.0 & 10.4 & 3.4 & 272.1 \\
TZ & 18.6 & 90.0 & 85.1 & 25.7 & 0.2 & 11.0 & 3.0 & 275.1 \\
Region & 16.4 & 89.4 & 89.8 & 28.8 & 0.3 & 10.9 & 3.9 & 277.5 \\
\hline
\end{tabular}


(NAO) and the Arctic Oscillation (AO) indices were collected from the NOAA Climate Prediction Center (NOAA CPC 2017). In addition, links with the Atlantic Multidecadal Oscillation (AMO) (i.e. sea surface temperatures variability over the North Atlantic) were also assessed, as earlier studies determined that the AMO is positively correlated with the global mean annual surface land temperature (Muller et al. 2013). Data on the AMO index were obtained from NOAA Earth System Research Laboratory Physical Sciences Division (NOAA/ESRL PSD 2017). The Pearson correlation coefficients were calculated in XLSTAT Version 2014.5.03 for these relations quantification.

\section{Results}

The decadal linear trends in annual extreme temperature indices in the period 1961-2016 are shown in Table 6. Linear trends of the regional averaged indices slope and error estimates, statistical significance ( $p$-value) and coefficient of determination $\left(\mathrm{R}^{2}\right)$ - are displayed in Figures 2-5.

The analysis of the absolute temperature indices showed upward trends for all indices (Figure 2 and Table 6). However, the estimated trends for maximum values of daily maximum and minimum temperatures TXx and TNx were much more prominent and with higher confidence levels over the entire territory - both

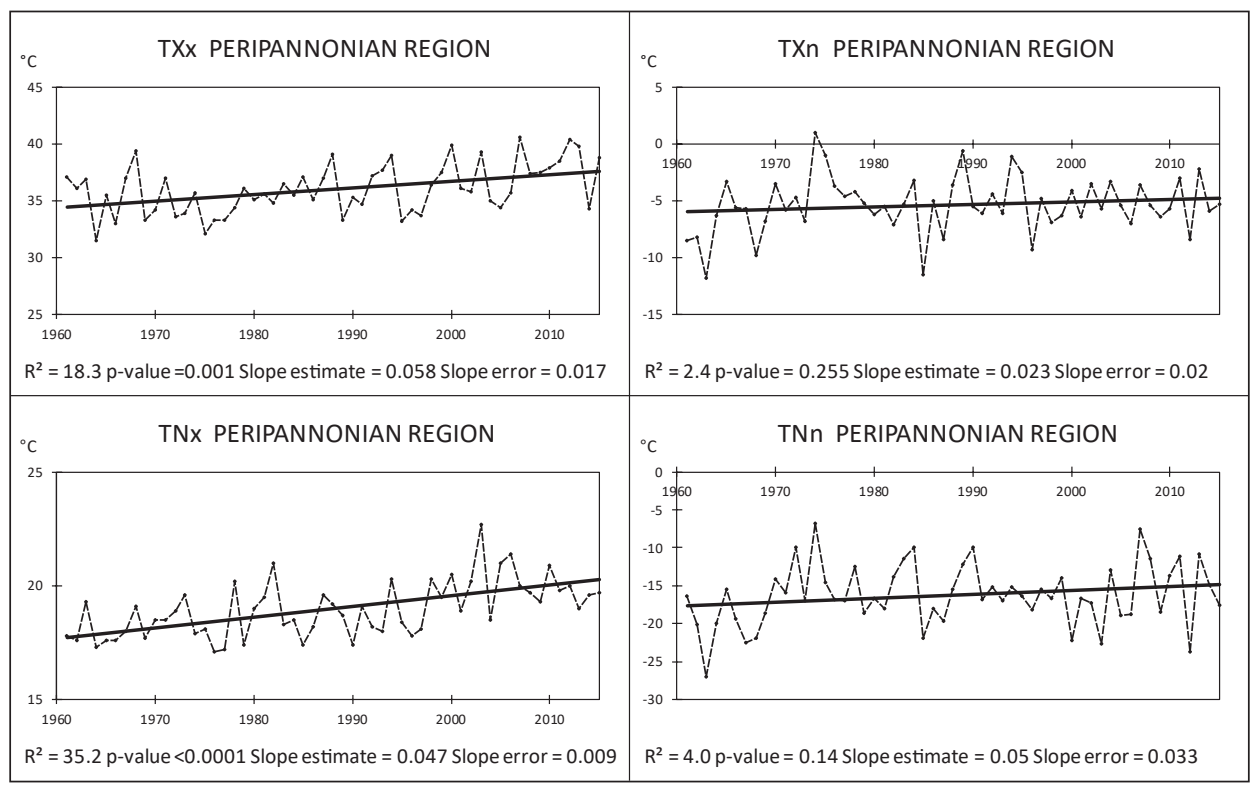

Fig. 2 - Linear trends in absolute indices in 1961-2016 
Table 6 - Decadal linear trends in annual extreme temperature indices in the period 1961-2016

\begin{tabular}{lcccccrrr}
\hline Index & TXx & TXn & TNx & TNn & TX10p & TX90p & TN10p & TN90p \\
\hline SM & $0.4^{\mathrm{b}}$ & 0.3 & $0.4^{\mathrm{a}}$ & 0.5 & $-3.5^{\mathrm{a}}$ & $8.3^{\mathrm{a}}$ & $-5.0^{\mathrm{a}}$ & $8.8^{\mathrm{a}}$ \\
BL & $0.7^{\mathrm{a}}$ & 0.3 & $0.7^{\mathrm{a}}$ & $0.6^{\mathrm{a}}$ & $-4.7^{\mathrm{a}}$ & $11.5^{\mathrm{a}}$ & $-6.1^{\mathrm{a}}$ & $14.1^{\mathrm{a}}$ \\
DB & $0.6^{\mathrm{b}}$ & 0.2 & $0.4^{\mathrm{a}}$ & 0.6 & $-4.7^{\mathrm{a}}$ & $8.7^{\mathrm{a}}$ & $-4.1^{\mathrm{a}}$ & $8.7^{\mathrm{a}}$ \\
TZ & $0.7^{\mathrm{a}}$ & 0.3 & $0.4^{\mathrm{a}}$ & 0.3 & $-4.5^{\mathrm{a}}$ & $10.8^{\mathrm{a}}$ & $-3.9^{\mathrm{a}}$ & $8.6^{\mathrm{a}}$ \\
Region & $0.6^{\mathrm{a}}$ & 0.2 & $0.5^{\mathrm{a}}$ & 0.5 & $-4.6^{\mathrm{a}}$ & $9.0^{\mathrm{a}}$ & $-4.7^{\mathrm{a}}$ & $10.2^{\mathrm{a}}$ \\
\hline Index & IDO & FDO & SU25 & SU30 & TR20 & WSDI & CSDI & GSL \\
\hline SM & $-2.4^{\mathrm{a}}$ & $-3.5^{\mathrm{b}}$ & $5.6^{\mathrm{a}}$ & $4.8^{\mathrm{a}}$ & $0.1^{\mathrm{a}}$ & $4.1^{\mathrm{a}}$ & $-0.8^{\mathrm{c}}$ & $5.3^{\mathrm{c}}$ \\
BL & $-2.6^{\mathrm{a}}$ & $-5.8^{\mathrm{a}}$ & $7.7^{\mathrm{a}}$ & $6.8^{\mathrm{a}}$ & $0.9^{\mathrm{a}}$ & $6.5^{\mathrm{a}}$ & $-0.9^{\mathrm{c}}$ & $9.1^{\mathrm{a}}$ \\
DB & $-2.2^{\mathrm{b}}$ & $-2.8^{\mathrm{c}}$ & $5.4^{\mathrm{a}}$ & $5.0^{\mathrm{a}}$ & $0.5^{\mathrm{a}}$ & $5.4^{\mathrm{a}}$ & $-0.8^{\mathrm{d}}$ & $5.7^{\mathrm{b}}$ \\
TZ & $-2.5^{\mathrm{a}}$ & $-3.2^{\mathrm{b}}$ & $6.4^{\mathrm{a}}$ & $5.5^{\mathrm{a}}$ & $0.1^{\mathrm{a}}$ & $5.6^{\mathrm{a}}$ & $-0.6^{\mathrm{a}}$ & $6.7^{\mathrm{b}}$ \\
Region & $-2.4^{\mathrm{a}}$ & $-3.9^{\mathrm{b}}$ & $6.5^{\mathrm{a}}$ & $5.3^{\mathrm{a}}$ & $0.1^{\mathrm{a}}$ & $5.5^{\mathrm{a}}$ & $-0.9^{\mathrm{d}}$ & $7.8^{\mathrm{a}}$ \\
\hline
\end{tabular}

Confidence level at $99.9 \%\left({ }^{\mathrm{a}}\right), 99 \%\left({ }^{b}\right), 95 \%\left({ }^{c}\right)$ and $90 \%\left({ }^{d}\right)$

$0.4-0.7^{\circ} \mathrm{C}$ per decade - than the trends in minimum values of daily maximum and minimum temperatures, which were mostly insignificant, particularly for TXn.

Trends in percentile-based indices (Figure 3 and Table 6) also indicate warming tendency. During the observed period, warm days (TX90p) and warm nights (TN90p) showed significant upward trends, whereas the annual number of cold

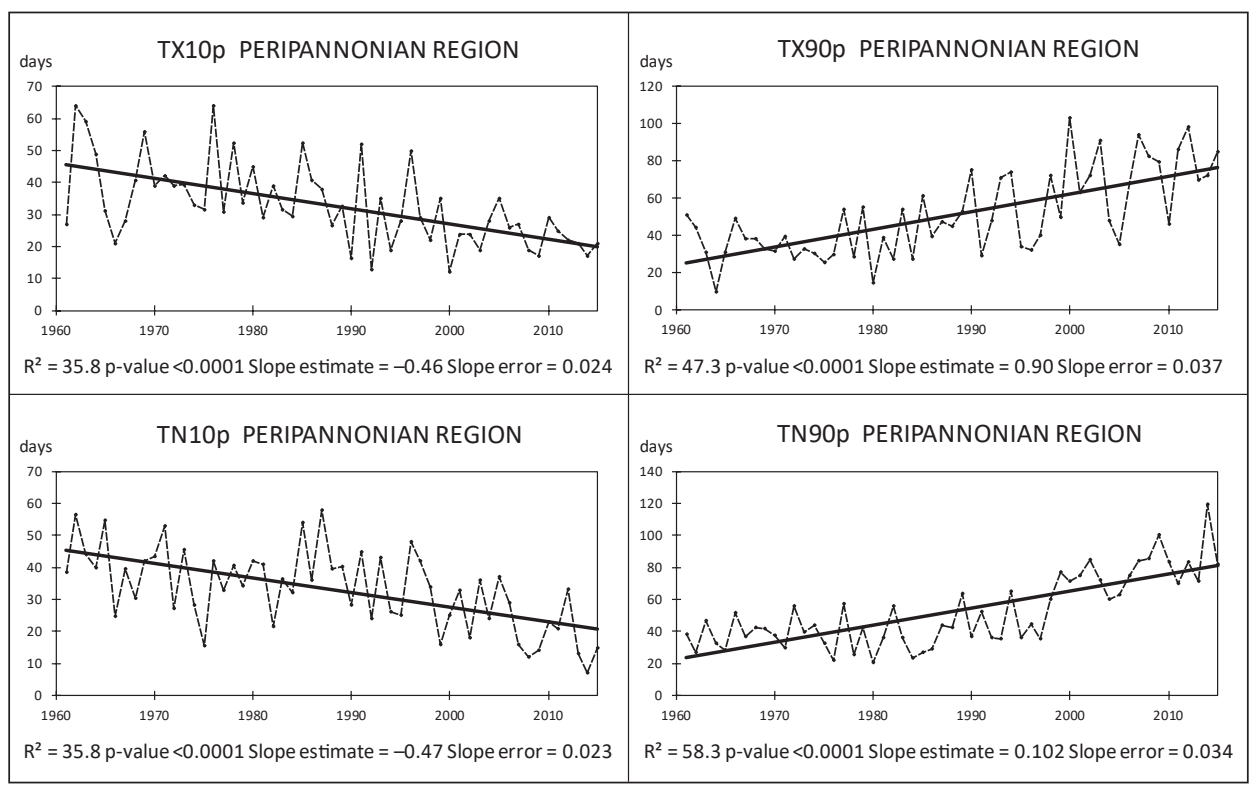

Fig. 3 - Linear trends in percentile-based indices in 1961-2016 
days (TX10p) and cold nights (TN10p) significantly declined. These trends were also consistent with the trends observed globally and continentally (Donat et al. 2013; Morak, Hegerl, Christidis 2013). Over the study area the annual increase in the occurrence of TN90p and TX90p 8.6-14.1 days per decade and 8.3-11.5 days per decade, respectively - was much more prominent than decline in TN10p and TX10p: from -3.9 to -6.1 days per decade and from -3.5 to -4.7 days per decade, respectively. In the western part of the region nighttime temperatures have increased more than daytime ones, whereas the opposite was registered in the east.

The observed trends in threshold-based temperature indices were also consistent with warming tendency (Figure 4 and Table 6). The annual occurrence of indices of cold temperature extremes IDO and FDO displayed a significant downward tendency (from -2.2 to -2.6 days per decade and from -2.8 to -5.8 days per decade, respectively), whereas the significant (and much more prominent) upward trends in indices of warm temperature extremes SU25 (5.4-7.7 days per decade) and SU30 (4.8-6.8 days per decade) were found. Although still rare in occurrence, TR20 have also recorded a significant increasing trend during the observed period (0.1-0.9 days per decade).

Globally, periods of extremely hot weather (i.e. warm spells) last longer, whereas periods of extremely cold weather (i.e. cold spells) have become shorter since the mid- $20^{\text {th }}$ century - the occurrence of warm (cold) spells significantly increased (decreased) for 8(4) days per decade (Donat et al. 2013). During the

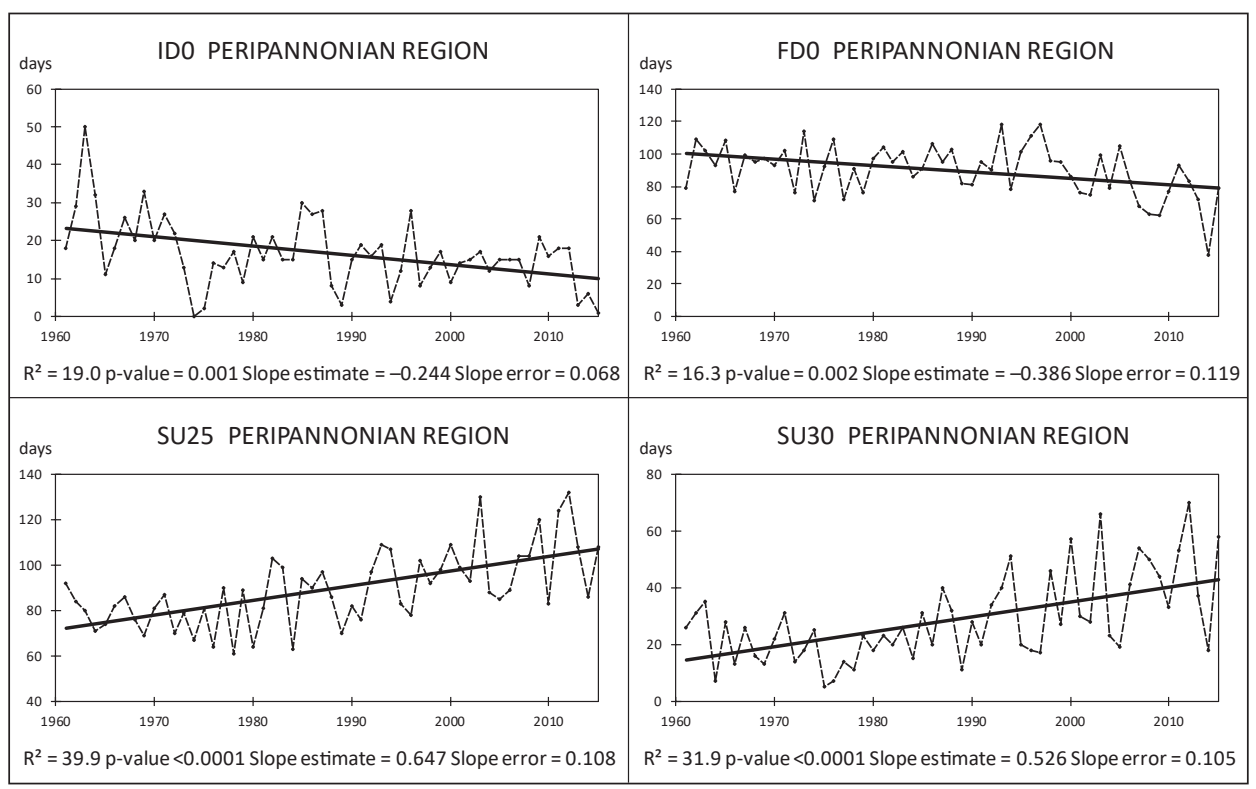

Fig. 4 - Linear trends in fixed threshold-based indices in 1961-2016 
Table 7 - Decadal linear trends in seasonal extreme temperature indices in the period 1961-2016

\begin{tabular}{|c|c|c|c|c|c|c|c|c|c|c|}
\hline Station & $S M$ & $\mathrm{BL}$ & DB & $\mathrm{TZ}$ & Region & SM & $B L$ & DB & $\mathrm{TZ}$ & Region \\
\hline Index & & & Winter & & & & & Spring & & \\
\hline TXX & $0.4^{c}$ & $0.7^{\mathrm{a}}$ & $0.7^{b}$ & $0.6^{\mathrm{b}}$ & $0.6^{b}$ & $0.6^{\mathrm{b}}$ & $0.8^{\mathrm{b}}$ & $0.5^{b}$ & $0.7^{b}$ & $0.6^{b}$ \\
\hline TXn & $0.4^{d}$ & 0.3 & 0.3 & 0.3 & 0.3 & $0.5^{\mathrm{d}}$ & $0.5^{\mathrm{d}}$ & 0.4 & 0.3 & 0.4 \\
\hline TNx & $0.4^{\mathrm{d}}$ & $0.5^{c}$ & 0.2 & $0.4^{\mathrm{d}}$ & 0.3 & $0.3^{c}$ & $0.3^{c}$ & 0.2 & 0 & 0.2 \\
\hline TNn & 0.6 & $0.5^{d}$ & 0.6 & 0.3 & 0.4 & 0.3 & $0.5^{\mathrm{d}}$ & 0.3 & 0.4 & 0.3 \\
\hline TX10p & $-0.9^{d}$ & $-1.0^{c}$ & $-1.2^{\mathrm{c}}$ & -1.0 & $-1.0^{\mathrm{d}}$ & $-0.9^{c}$ & $-1.1^{\mathrm{b}}$ & $-0.9^{c}$ & $-0.8^{c}$ & $-0.9^{c}$ \\
\hline TX90p & $1.5^{\mathrm{b}}$ & $1.9^{\mathrm{b}}$ & $1.9^{\mathrm{b}}$ & $1.5^{\mathrm{b}}$ & $1.4^{\mathrm{b}}$ & $2.0^{\mathrm{b}}$ & $2.4^{\mathrm{a}}$ & $1.8^{\mathrm{b}}$ & $1.6^{\mathrm{b}}$ & $1.8^{\mathrm{b}}$ \\
\hline TN10p & $-1.2^{c}$ & $-1.3^{c}$ & $-1.1^{\mathrm{d}}$ & -0.7 & $-1.0^{\mathrm{d}}$ & $-0.9^{c}$ & $-1.2^{\mathrm{b}}$ & $-0.9^{c}$ & $-0.8^{\mathrm{d}}$ & $-1.0^{\mathrm{b}}$ \\
\hline TN90p & $1.6^{\mathrm{b}}$ & $2.4^{\mathrm{a}}$ & $1.7^{c}$ & $1.4^{\mathrm{c}}$ & $1.9^{\mathrm{b}}$ & $1.7^{\mathrm{b}}$ & $2.5^{\mathrm{a}}$ & $1.6^{\mathrm{b}}$ & $1.1^{\mathrm{c}}$ & $1.7^{\mathrm{b}}$ \\
\hline Index & & & Summer & & & & & Autumn & & \\
\hline$T X x$ & $0.5^{c}$ & $0.8^{\mathrm{b}}$ & $0.6^{c}$ & $0.7^{\mathrm{a}}$ & $0.6^{b}$ & -0.1 & 0.1 & 0.2 & 0.3 & 0.1 \\
\hline$T X n$ & 0.3 & 0.3 & 0.2 & 0.3 & 0.2 & 0.1 & 0.2 & 0.3 & 0.1 & 0.2 \\
\hline TNx & $0.4^{\mathrm{a}}$ & $0.6^{\mathrm{a}}$ & $0.4^{\mathrm{b}}$ & $0.3^{\mathrm{b}}$ & $0.4^{\mathrm{a}}$ & 0.1 & $0.6^{\mathrm{b}}$ & $0.3^{b}$ & $0.3^{\mathrm{d}}$ & $0.4^{b}$ \\
\hline $\mathrm{TNn}$ & $0.4^{\mathrm{b}}$ & $0.4^{\mathrm{b}}$ & $0.5^{\mathrm{b}}$ & $0.3^{\mathrm{b}}$ & $0.4^{\mathrm{b}}$ & 0.3 & 0.4 & 0.3 & $0.4^{\mathrm{d}}$ & 0.3 \\
\hline TX10p & $-1.2^{b}$ & $-1.5^{a}$ & $-1.4^{\mathrm{b}}$ & $-1.3^{\mathrm{b}}$ & $-1.5^{a}$ & 0 & $-0.7^{d}$ & -0.4 & -0.5 & -0.4 \\
\hline TX90p & $3.9^{\mathrm{a}}$ & $4.6^{\mathrm{a}}$ & $3.2^{\mathrm{b}}$ & $4.5^{\mathrm{a}}$ & $3.9^{\mathrm{a}}$ & $0.9^{\mathrm{d}}$ & $1.9^{\mathrm{a}}$ & $1.2^{\mathrm{c}}$ & $1.9^{\mathrm{b}}$ & $1.3^{\mathrm{c}}$ \\
\hline TN10p & $-1.5^{a}$ & $-1.7^{\mathrm{a}}$ & $-1.6^{\mathrm{a}}$ & $-1.4^{b}$ & $-1.6^{\mathrm{a}}$ & $-0.8^{\mathrm{d}}$ & $-1.0^{c}$ & -0.2 & -0.1 & -0.6 \\
\hline TN90p & $4.1^{\mathrm{a}}$ & $6.4^{\mathrm{a}}$ & $4.3^{\mathrm{a}}$ & $4.0^{\mathrm{a}}$ & $4.8^{\mathrm{a}}$ & $1.1^{\mathrm{d}}$ & $2.4^{\mathrm{b}}$ & $1.1^{\mathrm{d}}$ & $1.4^{\mathrm{c}}$ & $1.4^{\mathrm{c}}$ \\
\hline
\end{tabular}

Confidence level at $99.9 \%\left({ }^{\mathrm{a}}\right), 99 \%\left({ }^{b}\right), 95 \%\left({ }^{c}\right)$ and $90 \%\left({ }^{d}\right)$

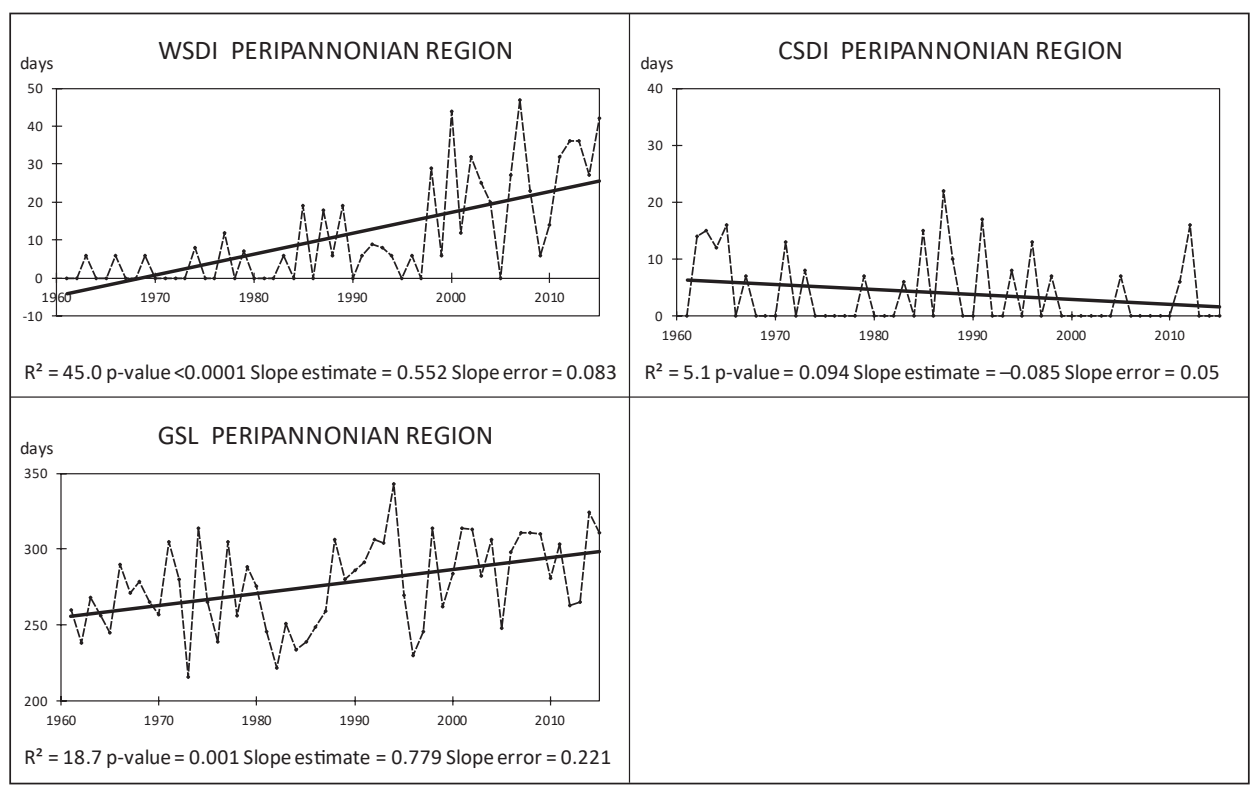

Fig. 5 - Linear trends in duration-based indices in 1961-2016 


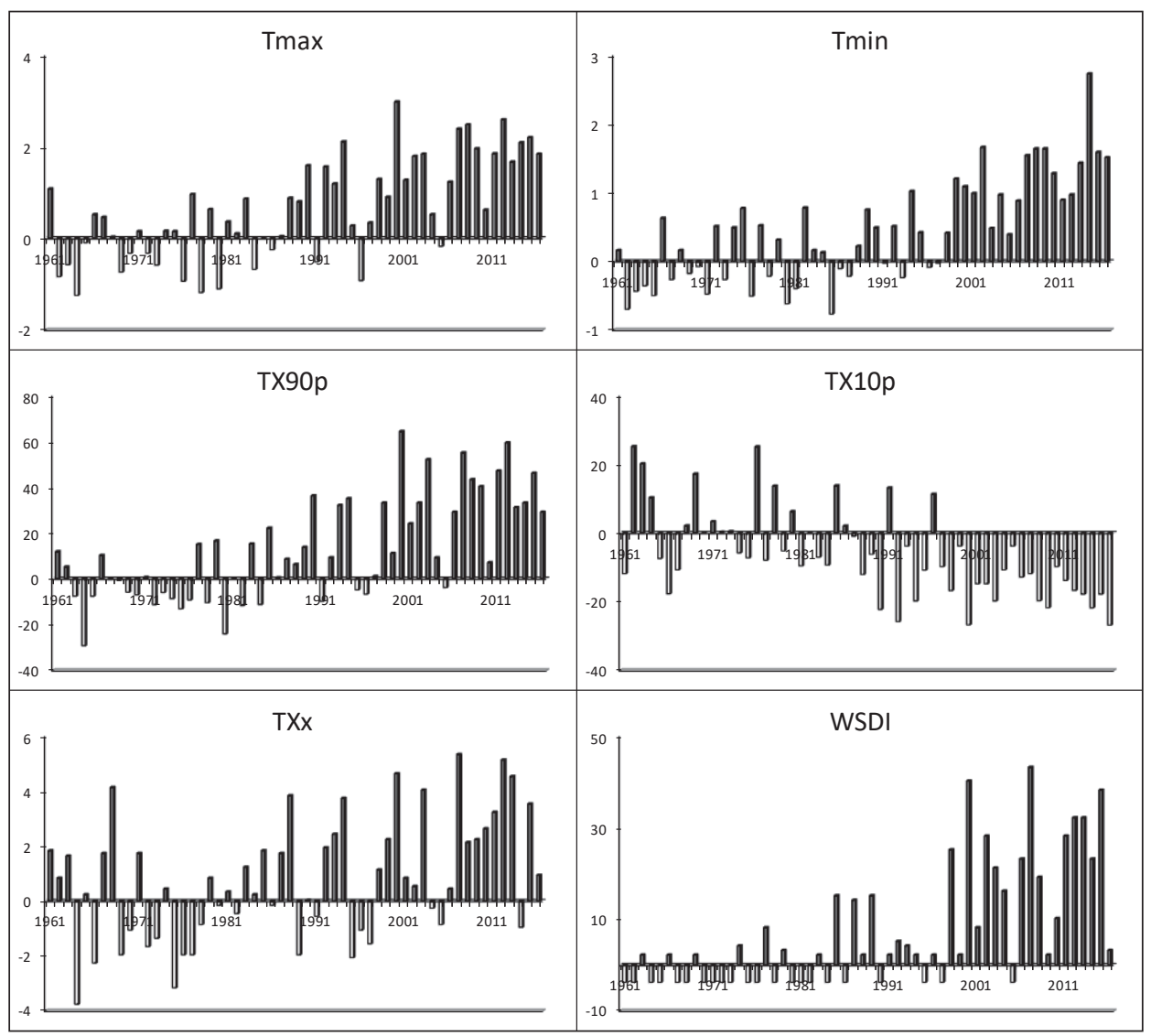

Fig. 6a - Deviations of the selected indices (regional average) from the 1961-1990 averages

observed period, the prominent and significant positive WSDI trends in the range of 4.1-6.5 days per decade were found over the entire study area (Figure 5 and Table 6). This follows the results of Lakatos et al. (2016) who determined the upward regional trend of 4.1 days per decade. WSDI has been rapidly increasing since the beginning of the $21^{\text {st }}$ century. The average annual number of WSDI in that period was 6-fold compared to the period 1961-1990 average. Moreover, majority of most severe and long-lasting heat waves in Europe since 1950 have been registered in the $21^{\text {st }}$ century (Russo, Sillmann, Fischer 2015). Over the Peripannonian region, severe heat waves occurred in 2003, 2007, 2012 and 2015. This follows the findings of Unkašević and Tošić (2015) obtained for Serbia, where the strongest and the longest heat waves were recorded in summer 2007 and 2012, respectively. Unlike the WSDI, only a slight decreasing trend was determined for CSDI from -0.6 to -0.9 days per decade (significant only in the western part of the region). The growing season length (GSL) was significantly extended for 5.3-9.1 days per decade. 


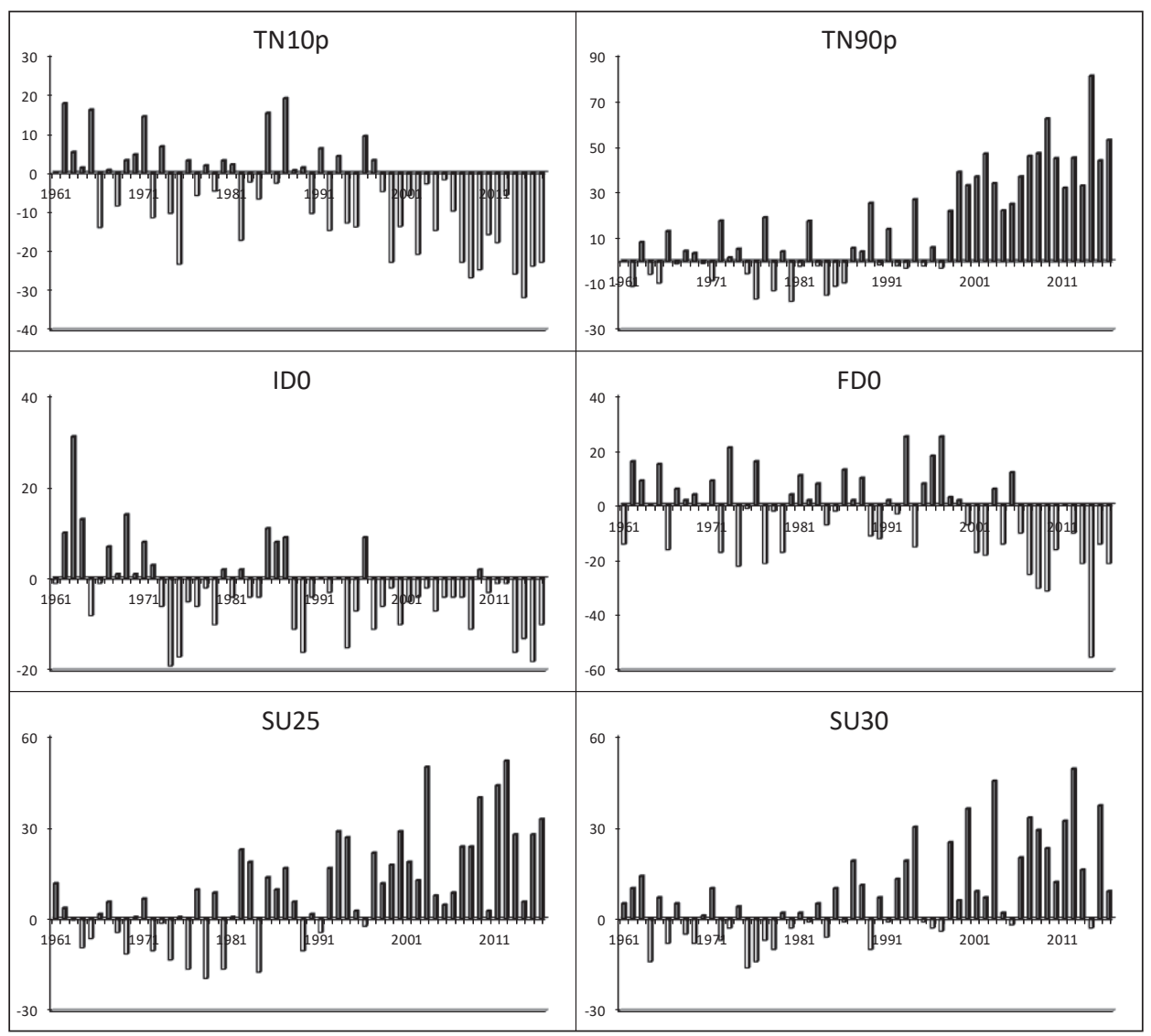

Fig. 6b - Deviations of the selected indices (regional average) from the 1961-1990 averages

Seasonal trend analysis (Table 7) showed that the warming was present throughout the year, but most pronounced in summer. The highest positive trend values for absolute indices (e.g. TXx $0.5-0.8^{\circ} \mathrm{C}$ per decade) and the greatest increase (decrease) in warm (cold) days and nights (e.g. TX90p and TN90p 3.2-4.6 days per decade and 4.0-6.4 days per decade, respectively) were registered in this part of the year, and then in winter and spring, whereas the least changes were manifested in autumn.

Changes in all extreme temperature indices over the Peripannonian region of Bosnia and Herzegovina became stronger in the last quarter of the $20^{\text {th }}$ century and particularly since the beginning of the $21^{\text {st }}$ century. Increasing warming tendency also suggests the fact that the 10 warmest years in the Peripannonian region of Bosnia and Herzegovina have been recorded after 1990 - only one of them prior to 2000 (1994 for Tmax and 1999 for Tmin). Among years with the highest (lowest) values of warm (cold) temperature indices, there were also only 
a few years prior to 1990 (the vast majority of them was recorded in the $21^{\text {st }}$ century). For instance, the extremely low values of cold-related temperature indices TX10p, TN10p, IDO and FDO were recorded in the hottest year - in 2014, there were only 15-22 TX10p, 2-13 TN10p, 34-52 FD0, 4-6 ID0 and without a single occurrence of CSDI. The maximum (minimum) frequency of warm (cold)-related indices was recorded in very warm years with the occurrence of severe and longlasting heat waves - in 2000, 2003, 2007, 2012 and 2015. For instance, in 2012, there were even 86-106 TX90p, 66-109 TN90p, 119-135 SU25, 63-82 SU30 and 34-45 WSDI.

The annual extreme temperature indices deviations from the period 1961-1990 averages (Figure 6) also confirm that warming becomes stronger since the beginning of the $21^{\text {st }}$ century. In that period, the indices of warm (cold) temperature extremes were predominantly above (below) averages. Tmin, SU25 and TN90p registered not a single occurrence below the average, whereas Tmax, TX90p, WSDI showed only one such year - 2005. In contrast, the annual frequency of the coldrelated indices was mostly below the average (TX10p and TN10p in all years, IDO and FDO with only one or two years above the average).

Changes in distribution of Tmax and Tmin between the 1961-1990 and 1987-2016 clearly indicate a significant shift towards warmer temperatures. As expected, indices of warm temperature extremes shifted their distributions towards higher values, whereas the corresponding shift to lower values was detected for cold-related indices. The Kolmogorov-Smirnov test results confirmed significant distributional changes between two periods. The insignificant changes were determined only for TXn and TNn (and TR2O and CSDI due to theirs very rare occurrence over this area). The changes were particularly pronounced in the upper tail of the warm-related indices distributions.

\section{Discussion and conclusions}

A general increase in annual Tmax and Tmin (statistically significant in some areas) during the period 1911-1990 was a typical feature of air temperature fluctuation during the $20^{\text {th }}$ century in the central European region (Brázdil et al. 1996). During the second half of the $20^{\text {th }}$ century, the absolute temperature indices have also showed an upward tendency (Alexander et al. 2006, Donat et al. 2013). Globally, the warming was generally stronger for the minimum than for the maximum values (Donat et al. 2013). Globally averaged, TNn increased per about $3{ }^{\circ} \mathrm{C}$ (Donat et al. 2013). TNx and TXx increased about $1^{\circ} \mathrm{C}$ over much of European continent (Donat et al. 2013). Unlike the results of global (Alexander et al. 2006) and European (Klein Tank, Können 2003) scale studies, over the Peripannonian region of Bosnia and Herzegovina greater warming tendency 
was found for Tmax than for Tmin $\left(0.4-0.6{ }^{\circ} \mathrm{C}\right.$ per decade vs. $0.3-0.5^{\circ} \mathrm{C}$ per decade). However, stated follows the results of previous research in other parts of the Peripannonian region. The maximum temperatures in Serbia and Croatia showed greater changes (in the range of $0.3-0.4^{\circ} \mathrm{C}$ per decade), than minimum temperatures which largely increased by $0.2-0.3^{\circ} \mathrm{C}$ per decade (Branković et al. 2013; Malinovic-Milicevic et al. 2016). In Slovakia, daily maximum and minimum temperatures showed a significant upward trend for the year, summer and spring (daily minimum temperature also showed significant positive trend in autumn season; Damborská et al. 2016). Further, these studies have also determined higher increase in maximum values of daily maximum and minimum temperatures $\left(0.4-0.7^{\circ} \mathrm{C}\right.$ per decade) than in minimum ones $\left(0.2-0.3^{\circ} \mathrm{C}\right.$ per decade). The likelihood of extreme annual maximum and minimum daily temperatures also changed globally - the return period for extreme annual TNn and TXn events that were expected to recur once every 20 years in the 1960s are now exceeded in 35 and 30 years, respectively, whereas, the return periods for circa 1960 s 20 years extremes of annual TNx and TXx are estimated to have decreased to fewer than 10 and 15 years, respectively (Zwiers, Zhang, Feng 2011). Trends in percentile-based indices over the Peripannonian region of Bosnia and Herzegovina were also consistent with the trends observed globally (Donat et al. 2013; Morak, Hegerl, Christidis 2013) and continentally (Klein Tank, Können 2003). Global analysis showed that the changes were most pronounced in the annual occurrence of TN10p, then in the frequency of TN90p, whereas the least were in TX90p frequency (Morak, Hegerl, Christidis 2013). Hemispherically averaged numbers of warm days and warm nights have showed an increase in the range of approximately 7-9 days since the 1970s, whereas the frequency of cold days and cold nights decreased for approximately 5-6 days (Morak, Hegerl, Christidis 2013). However, over the study area the annual increase in the occurrence of TN90p and TX90p was much more prominent than decline in TN10p and TX10p. Similar patterns of change were also found in other parts of the Pannonian region. In Croatia, most prominent trends were determined for the occurrence of TN90p (8-12 days per decade) and TX90p (6-10 days per decade; Branković et al. 2013). In Austria, significant increasing trends in the number of warm nights (days) and decreasing trends in number of cold nights (days) were found at almost all stations (Nemec et al. 2013). Trends in threshold-based temperature indices found over the Peripannonian region of Bosnia and Herzegovina were also consistent with changes observed globally (Alexander et al. 2006; Frich et al. 2002), in Europe at the continental scale (Klein Tank, Können 2003) and in other parts of the Pannonian region (Branković et al. 2013; Lakatos et al. 2016; Ruml et al. 2017). Regionally averaged, IDO and FDO displayed decreasing trends: -1.8 days per decade and -2.5 days per decade, respectively, whereas increase in SU25 was even higher (3.7 days per decade; Lakatos et al. 2016). At majority 
Table 8 - Pearson correlation coefficient between annual teleconection patterns indices and extreme temperature indices (regional average) in the period 1961-2016

\begin{tabular}{|c|c|c|c|c|c|c|c|c|c|}
\hline Variable & Tmax & Tmin & TXx & TXn & TNx & TNn & TX10p & TX90p & TN10p \\
\hline EA & $0.664^{a}$ & $0.663^{a}$ & $0.387^{b}$ & -0.028 & $0.608^{a}$ & 0.050 & $-0.634^{a}$ & $0.642^{\mathrm{a}}$ & $-0.506^{a}$ \\
\hline NAO & 0.150 & 0.106 & -0.041 & $0.455^{b}$ & -0.102 & $0.403^{b}$ & -0.145 & 0.095 & -0.150 \\
\hline $\mathrm{AO}$ & $0.377^{b}$ & $0.258^{d}$ & 0.104 & $0.379^{b}$ & 0.084 & $0.325^{c}$ & $-0.314^{c}$ & $0.297^{c}$ & $-0.282^{c}$ \\
\hline Variable & TN90p & IDO & FD0 & SU25 & SU30 & TR20 & WSDI & CSDI & GSL \\
\hline EA & $0.703^{a}$ & $-0.338^{c}$ & $-0.500^{a}$ & $0.601^{a}$ & $0.483^{b}$ & $0.429^{b}$ & $0.564^{a}$ & $-0.251^{d}$ & $0.402^{b}$ \\
\hline NAO & -0.066 & $-0.255^{d}$ & -0.049 & 0.051 & -0.024 & $-0.291^{c}$ & 0.028 & -0.170 & 0.082 \\
\hline $\mathrm{AO}$ & 0.118 & $-0.359^{b}$ & -0.073 & $0.243^{d}$ & 0.189 & -0.157 & 0.176 & -0.156 & 0.214 \\
\hline
\end{tabular}

Confidence level at $99.9 \%\left({ }^{a}\right), 99 \%\left({ }^{b}\right), 95 \%\left({ }^{c}\right)$ and $90 \%\left({ }^{d}\right)$

Table 9 - Pearson correlation coefficient between seasonal teleconection patterns indices and extreme temperature indices (regional average) in the period 1961-2016

\begin{tabular}{lcccccc}
\hline Variable & EA winter & EA spring & EA $_{\text {summer }}$ & EA $_{\text {autumn }}$ & NAO $_{\text {winter }}$ & $A_{\text {spring }}$ \\
\hline Tmax & $0.632^{\mathrm{a}}$ & $0.475^{\mathrm{b}}$ & $0.614^{\mathrm{a}}$ & $0.525^{\mathrm{a}}$ & $0.452^{\mathrm{b}}$ & $0.396^{\mathrm{b}}$ \\
Tmin & $0.581^{\mathrm{a}}$ & $0.429^{\mathrm{b}}$ & $0.613^{\mathrm{a}}$ & $0.484^{\mathrm{b}}$ & $0.323^{\mathrm{c}}$ & $0.320^{\mathrm{c}}$ \\
TXx & $0.439^{\mathrm{b}}$ & $0.436^{\mathrm{b}}$ & $0.482^{\mathrm{b}}$ & $0.280^{\mathrm{c}}$ & 0.090 & 0.030 \\
TXn & $0.369^{\mathrm{b}}$ & 0.194 & $0.246^{\mathrm{d}}$ & 0.218 & $0.256^{\mathrm{d}}$ & $0.266^{\mathrm{c}}$ \\
TNx & $0.370^{\mathrm{b}}$ & $0.269^{\mathrm{c}}$ & $0.580^{\mathrm{a}}$ & $0.388^{\mathrm{b}}$ & -0.103 & 0.131 \\
TNn & $0.423^{\mathrm{b}}$ & 0.151 & $0.316^{\mathrm{c}}$ & $0.312^{\mathrm{c}}$ & $0.268^{\mathrm{c}}$ & $0.331^{\mathrm{c}}$ \\
TX10p & $-0.429^{\mathrm{b}}$ & $-0.425^{\mathrm{b}}$ & $-0.512^{\mathrm{a}}$ & $-0.596^{\mathrm{a}}$ & $-0.465^{\mathrm{b}}$ & -0.210 \\
TX90p & $0.615^{\mathrm{a}}$ & $0.402^{\mathrm{b}}$ & $0.602^{\mathrm{a}}$ & $0.415^{\mathrm{b}}$ & $0.241^{\mathrm{d}}$ & $0.296^{\mathrm{c}}$ \\
TN10p & $-0.491^{\mathrm{a}}$ & $-0.292^{\mathrm{c}}$ & $-0.434^{\mathrm{b}}$ & $-0.375^{\mathrm{b}}$ & $-0.371^{\mathrm{b}}$ & $-0.301^{\mathrm{c}}$ \\
TN90p & $0.542^{\mathrm{a}}$ & $0.506^{\mathrm{a}}$ & $0.657^{\mathrm{a}}$ & $0.487^{\mathrm{a}}$ & 0.099 & $0.265^{\mathrm{c}}$ \\
\hline
\end{tabular}

Confidence level at $99.9 \%\left({ }^{a}\right), 99 \%\left({ }^{b}\right), 95 \%\left({ }^{c}\right)$ and $90 \%\left({ }^{d}\right)$

of Croatian stations, the increase in the number of SU25 was in the range of 2-8 days per decade, whereas decline in FDO was lower in magnitude (mostly up to 2 days per decade; Branković et al. 2013).

Over the Peripannonian region of Bosnia and Herzegovina, the highest trend values were estimated for indices of warm temperature extremes - TXx, TNx, TX90p, TN90p, WSDI, SU25 and SU30. This is also consistent with previous studies' findings (Bartholy, Pongrácz 2007; Branković et al. 2013; Croitoru, Piticar 2014; Ruml et al. 2017; Unkašević, Tošić 2013). A regional scale study found the highest trend values (more than 6 days per decade) for TN90p, TX90p, SU25 and SU30 (Bartholy, Pongrácz 2007). Analysis for the Romanian part of the Pannonian Basin revealed that the strongest increase was also found for warm-related indices SU30, SU25, TX90p and TXx (Croitoru, Piticar 2014). Graczyk et al. (2017) detected 
Table 10 - Pearson correlation coefficient between the annual AMO and extreme temperature indices (regional average) in the period 1961-2016

\begin{tabular}{ccccccccc}
\hline Tmax & TXx & TXn & TNx & TNn & TX10p & TX90p & TN10p & TN90p \\
\hline $0.463^{\mathrm{b}}$ & $0.325^{\mathrm{c}}$ & -0.18 & $0.565^{\mathrm{a}}$ & -0.120 & $-0.425^{\mathrm{b}}$ & $0.498^{\mathrm{a}}$ & $-0.319^{\mathrm{c}}$ & $0.615^{\mathrm{a}}$ \\
\hline Tmin & ID0 & FD0 & SU25 & SU30 & TR20 & WSDI & CSDI & GSL \\
\hline $0.479^{\mathrm{b}}$ & -0.1 & $-0.241^{\mathrm{d}}$ & $0.460^{\mathrm{b}}$ & $0.474^{\mathrm{b}}$ & $0.484^{\mathrm{b}}$ & $0.500^{\mathrm{a}}$ & -0.06 & $0.243^{\mathrm{d}}$ \\
\hline
\end{tabular}

Confidence level at $99.9 \%\left({ }^{\mathrm{a}}\right), 99 \%\left(^{\mathrm{b}}\right), 95 \%\left(^{\mathrm{c}}\right)$ and $90 \%\left(^{\mathrm{d}}\right)$

Table 11 - Pearson correlation coefficient between the seasonal AMO and extreme temperature indices (regional average) in the period 1961-2016

\begin{tabular}{lcccc|llrrr}
\hline Variable & Winter & Spring & Summer & Autumn & Variable & Winter & Spring & Summer & Autumn \\
\hline Tmax & 0.054 & 0.141 & $0.468^{\mathrm{b}}$ & $0.343^{\mathrm{b}}$ & Tmin & 0.019 & 0.159 & $0.653^{\mathrm{a}}$ & $0.385^{\mathrm{b}}$ \\
TXx & $0.271^{\mathrm{c}}$ & 0.217 & $0.257^{\mathrm{d}}$ & 0.109 & TX10p & 0.066 & -0.089 & $-0.314^{\mathrm{c}}$ & $-0.363^{\mathrm{b}}$ \\
TXn & -0.093 & -0.021 & 0.051 & 0.089 & TX90p & 0.099 & 0.122 & $0.502^{\mathrm{a}}$ & $0.393^{\mathrm{b}}$ \\
TNx & -0.058 & -0.016 & $0.565^{\mathrm{a}}$ & $0.362^{\mathrm{b}}$ & TN10p & 0.035 & -0.063 & $-0.422^{\mathrm{b}}$ & $-0.253^{\mathrm{d}}$ \\
TNn & -0.019 & -0.112 & $0.405^{\mathrm{b}}$ & 0.174 & TN90p & 0.143 & $0.264^{\mathrm{c}}$ & $0.740^{\mathrm{a}}$ & $0.427^{\mathrm{b}}$ \\
\hline
\end{tabular}

Confidence level at $99.9 \%\left({ }^{\mathrm{a}}\right), 99 \%\left({ }^{b}\right), 95 \%\left({ }^{c}\right)$ and $90 \%\left({ }^{d}\right)$

changes in the frequency of warm extremes occurrence over Poland for 8 out of 11 indices examined in the study.

Bartholy and Pongrácz (2007) stated that a strong warming tendency could be detected since the mid-1970 >s. The extremely mild winters and warm summers during the last two decades suggest that recent global warming is present on a regional scale (Dobrovolný et al. 2010). Significant changes in maximum and minimum temperatures (and the extreme indices derived from them) during the last few decades were related to the anthropogenic forcing (detectable and clearly separable from the natural signals; Christidis, Stott 2016; Kim et al. 2016; Zwiers, Zhang, Feng 2011).

Research showed that positive temperature anomalies in many regions of Europe (including the part of the continent where Bosnia and Herzegovina is located) are associated with the EA pattern (Rust et al. 2015). The observed warming in Europe was primarily associated with the prevailing positive phase of the EA pattern (Rust et al. 2015). The above-average temperatures and greater (lower) frequency and/or intensity of warm (cold)-related temperature indices were connected with its positive phase. Indices of warm (cold) temperature extremes showed the significant positive (negative) correlation with the EA pattern (insignificant only for TXn and TNn; Table 8). The highest correlation coefficients (>0.6) were determined for TN90p, TX90p, TX10p, TNx and SU25. A significant 
positive correlation with Tmax and Tmin was present throughout the year. The extreme temperature indices were also connected with the EA pattern in all seasons, but its impact was somewhat stronger during summer and winter (Table 9). The persistent and exceptionally strong positive phase of the NAO since the early 1980 s accounted for a substantial part of the warming over the European continent in winter (Hurrell, Van Loon 1997). In winter season, during the positive NAO phase, warmer maritime air masses are advected to Europe by stronger-thanaverage westerlies over the middle latitudes associated with low pressure anomalies over the region of the Icelandic low and anomalously high pressures across the subtropical Atlantic (Hurrell, Van Loon 1997; Rust et al. 2015). In Bosnia and Herzegovina, the NAO has the strongest influence on air temperatures precisely over the Peripannonian region (Trbić, Popov, Gnjato 2017). Significant positive correlations in winter were determined for both Tmax and Tmin, as well as for minimum values of Tmax and Tmin (similar was determined for the AO in spring season). A positive phase of the AO leads to increasing temperatures due to the reinforcement of westerly winds that bring warmth towards Europe (Milošević et al. 2017). These findings are in accordance with the results of Ruml et al. (2017) and Unkašević and Tošić (2013) obtained for Serbia, which also determined that annual extreme temperature indices were much more strongly correlated with the EA than with the NAO pattern (or the EA/WR pattern).

Since the mid- $19^{\text {th }}$ century and the beginning of instrumental measurements, the AMO has showed two $65-80$ years cycles with a $0.4{ }^{\circ} \mathrm{C}$ amplitude between extremes of positive (warm) and negative (cool) phases (Gray et al. 2004). The AMO entered in its positive phase in the mid-1990s and this phase still lasts (Alexander, Halimeda Kilbourne, Nye 2014). Since then, the temperature increase also becomes more prominent. The significant positive correlation with the AMO index was determined for both Tmax and Tmin over the Peripannonian region (correlation coefficients 0.463 and 0.479 , respectively; Table 10). The indices of warm temperature extremes also displayed the significant positive relations with the AMO (the highest correlation coefficients were determined for TN90p, TNx, WSDI and TX90p). The opposite, correlation with indices of cold temperature extremes was negative and mostly insignificant (particularly for indices derived from Tmin). In summer and autumn, there were statistically significant correlations, whereas in other seasons the correlations were small and not statistically significant (Table 11). 


\section{References}

ALEXANDER, L.V., ZHANG, X., PETERSON, T.C., CAESAR, J., GLEASON, B., KLEIN TANK, A.M.G., HAYLOCK, M., COLLINS, D., TREWIN, B., RAHIMZADEH, F., TAGIPOUR, A., RUPA KUMAR, K., REVADEKAR, J., GRIFFITHS, G., VINCENT, L., STEPHENSON, D. B., BURN, J., AGUILAR, E., BRUNET, M., TAYLOR, M., NEW, M., ZHAI, P., RUSTICUCCI, M., VAZQUEZ-AGUIRRE, J.L. (2006): Global Observed Changes in Daily Climate Extremes of Temperature and Precipitation. Journal of Geophysical Research: Atmospheres, 111, D05109.

ALEXANDER, M.A., HALIMEDA KILBOURNE, K., NYE, J.A. (2014): Climate Variability during Warm and Cold Phases of the Atlantic Multidecadal Oscillation (AMO) 1871-2008. Journal of Marine Systems, 133, 14-26.

ANDRADE, C., LEITE, S.M., SANTOS, J.A. (2012): Temperature Extremes in Europe: Overview of Their Driving Atmospheric Patterns. Natural Hazards and Earth System Sciences, $12,1671-1691$.

BARTHOLY, J., PONGRÁCZ, R. (2007): Regional Analysis of Extreme Temperature and Precipitation Indices for the Carpathian Basin from 1946 to 2001. Global and Planetary Change, 57, 1-2, 83-95.

BRANKOVIĆ, Č., CINDRIĆ, K., GAJIĆ-ČAPKA, M., GÜTTLER, I., PANDŽIĆ, K., PATARČIĆ, M., SRNEC, L., TOMAŠEVIĆ, I., VUČETIĆ, V., ZANINOVIĆ, K. (2013): Sixth National Communication of the Republic of Croatia under the United Nation Framework Convention on the Climate Change (UNFCCC) Selected Sections in Chapters: 7. Climate Change Impacts and Adaptation Measures 8. Resarch, Systematic Observation and Monitoring. Meteorological and hydrological service of Croatia, Zagreb.

BRÁZDIL, R, BUDÍKOVÁ, M., AUER, I., BÖHM, R., CEGNAR, T., FAŠKO, P., LAPIN, M., GAJIĆ-ČAPKA, M., ZANINOVIĆ, K., KOLEVA, E., NIEDŹWIEDŹ, T., USTRNUL, Z., SZALAI, S., WEBER, R.O. (1996): Trends of Maximum and Minimum Daily Temperatures in CE and SE Europe. International Journal of Climatology, 16, 7, 765-782.

BRUGNARA, Y., AUCHMANN, R., BRÖNNIMANN, S., BOZZO, A., BERRO, D.C., MERCALLI, L. (2016): Trends of Mean and Extreme Temperature Indices Since 1874 at Low-Elevation Sites in the Southern Alps. Journal of Geophysical Research: Atmospheres, 121, 7, 3304-3325.

CALOIERO, T. (2017): Trend of Monthly Temperature and Daily Extreme Temperature during 1951-2012 in New Zealand. Theoretical and Applied Climatology, 129, 1-2, 111-127.

CHEN, D., WALTHER, A., MOBERG, A., JONES, P., JACOBEIT, J., LISTER, D. (2015): European Trend Atlas of Extreme Temperature and Precipitation Records. Springer, Dordrecht.

CHRISTIDIS, N., STOTT, P. A. (2016): Attribution Analyses of Temperature Extremes Using a Set of 16 Indices. Weather and Climate Extremes, 14, 24-35.

CROITORU, A.E., PITICAR, A. (2014): Changes in Hot Extreme Temperature Indices in Carpathian and Intra-Carpathian Areas of Romania. Energy and Clean Technology, Conference Proceedings, Volume: Renewable Energy Sources, Recycling, Air Pollution and Climate Changes, $14^{\text {th }}$ International Multidisciplinary Scientific Geoconference SGEM 2014, Albena, Bulgaria, 305-312.

DAMBORSKÁ, I., GERA, M., LAPIN, M., MELO, M., NEJEDLÍK, P. (2016): Changes in the Daily Range of the Air Temperature in the Mountainous Part of Slovakia within the Possible Context of Global Warming. Meteorologische Zeitschrift, 25, 1, 17-35.

DOBROVOLNÝ, P., BRÁZDIL, R., KOTYZA, O., VALÁŠEK, H. (2010): Extreme Summer and Winter Temperatures in the Czech Lands after A.D. 1500 and Their Central European Context. Geografie, 115, 3, 266-283. 
DONAT, M.G., ALEXANDER, L.V. (2012): The Shifting Probability Distribution of Global Daytime and Night-Time Temperatures. Geophysical Research Letters, 39, L14707.

DONAT, M.G., ALEXANDER, L.V., YANG, H., DURRE, I., VOSE, R., DUNN, R.J.H., WILLETT, K.M., AGUILAR, E., BRUNET, M., CAESAR, J., HEWITSON, B., JACK, C., KLEIN TANK, A.M.G., KRUGER, A.C., MARENGO, J., PETERSON, T.C., RENOM, M., ORIA ROJAS, C., RUSTICUCCI, M., SALINGER, J., ELRAYAH, A.S., SEKELE, S.S., SRIVASTAVA, A.K., TREWIN, B., VILLARROEL, C., VINCENT, L.A., ZHAI, P., ZHANG, X., KITCHING, S. (2013): Updated Analyses of Temperature and Precipitation Extreme Indices since the Beginning of the Twentieth Century: The Hadex2 Dataset. Journal of Geophysical Research: Atmospheres, 118, 2098-2118.

ETCCDI (2009): Climate Change Indices, Definitions of the 27 Core Indices, http://etccdi.pacificclimate.org/list_27_indices.shtml (8.2.2017).

FILAHI, S., TANARHTE, M., MOUHIR, L., EL MORHIT, M., TRAMBLAY, Y. (2016): Trends in Indices of Daily Temperature and Precipitations Extremes in Morocco. Theoretical and Applied Climatology, 124, 3, 959-972.

FIORAVANTI, G., PIERVITALI, E., DESIATO, F. (2016): Recent Changes of Temperature Extremes over Italy: An Index-Based Analysis. Theoretical and Applied Climatology, 123, $3,473-486$.

FONSECA, D., CARVALHO, M.J., MARTA-ALMEIDA, M., MELO-GONÇALVES, P., ROCHA, A. (2016): Recent Trends of Extreme Temperature Indices for the Iberian Peninsula. Physics and Chemistry of the Earth, Parts A/B/C, 94, 66-76.

FRICH, P., ALEXANDER, L.V., DELLA-MARTA, P., GLEASON, B., HAYLOCK, M., KLEIN TANK, A.M.G., PETERSON, T. (2002): Observed Coherent Changes in Climatic Extremes During the Second Half of the Twentieth Century. Climate Research, 19, 3, 193-212.

GRACZYK, D., PIŃSKWAR, I., KUNDZEWICZ, Z.W., HOV, Ø., FØRLAND, E.J., SZWED, M., CHORYŃSKI, A. (2017): The Heat Goes on - Changes in Indices of Hot Extremes in Poland. Theoretical and Applied Climatology, 129, 1-2, 459-471.

GRAY, S.T., GRAUMLICH, L.J., BETANCOURT, J.L., PEDERSON, G.T. (2004): A Tree-Ring Based Reconstruction of the Atlantic Multidecadal Oscillation since 1567 A.D. Geophysical Research Letters, 31, L12205.

HURRELL, J., VAN LOON, H. (1997): Decadal Variations in Climate Associated with the North Atlantic Oscillation. Climatic Change, 36, 3, 301-326.

IPCC (2014): Climate Change 2014: Synthesis Report. Contribution of Working Groups I, II and III to the Fifth Assessment Report of the Intergovernmental Panel on Climate Change Core Writing Team. IPCC, Geneva.

KIM, Y.H., MIN, S.K., ZHANG, X., ZWIERS, F., ALEXANDER, L.V., DONAT, M.G., TUNG, S.Y. (2016): Attribution of Extreme Temperature Changes during 1951-2010. Climate Dynamics, 46, 5-6, 1769-1782.

KIOUTSIOUKIS, I., MELAS, D., ZEREFOS, C. (2010): Statistical Assessment of Changes in Climate Extremes over Greece (1955-2002). International Journal of Climatology, 30, 11, 1723-1737.

KLEIN TANK, A.M.G., KÖNNEN, G.P. (2003): Trends Indices of Daily Temperature and Precipitation Extremes in Europe, 1946-1999. Journal of Climate, 16, 22, 3665-3680.

LAKATOS, M., BIHARI, Z., SZENTIMREY, T., SPINONI, J., SZALAI, S. (2016): Analyses of Temperature Extremes in the Carpathian Region in the period 1961-2010. Időjárás, 120, 1, 41-51. 
MALINOVIC-MILICEVIC, S., RADOVANOVIC, M.M., STANOJEVIC, G., MILOVANOVIC, B. (2016): Recent Changes in Serbian Climate Extreme Indices from 1961 to 2010. Theoretical and Applied Climatology, 124, 3, 1089-1098.

MILOŠEVIĆ, D.D., SAVIĆ, S.M., STANKOV, U., ŽIBERNA, I., PANTELIĆ, M.M., DOLINAJ, D., LEŠČEŠEN, I. (2017): Maximum Temperatures over Slovenia and Their Relationship with Atmospheric Circulation Patterns. Geografie, 122, 1, 1-20.

MORAK, S., HEGERL, G.C., CHRISTIDIS, N. (2013): Detectable Changes in the Frequency of Temperature Extremes. Journal of Climate, 26, 5, 1561-1574.

MULlER, R.A., CURRY, J., GROOM, D., JACOBSEN, R., PERLMUTTER, S., ROHDE, R., ROSENFELD, A., WICKHAM, C., WURTELE, J. (2013): Decadal Variations in the Global Atmospheric Land Temperatures. Journal of Geophysical Research: Atmospheres, 118, 11, 5280-5286.

NEMEC, J., GRUBER, C., CHIMANI, B., AUER, I. (2013): Trends in Extreme Temperature Indices in Austria Based on a New Homogenised Dataset. International Journal of Climatology, 33, 6, 1538-1550.

NOAA CPC (2017): Northern Hemisphere Teleconnection Patterns, http://www.cpc.ncep.noaa. gov/data/teledoc/telecontents.shtml (12.6.2017).

NOAA/ESRL PSD (2017): Climate Timeseries AMO (Atlantic Multidecadal Oscillation) Index, https://www.esrl.noaa.gov/psd/data/timeseries/AMO/ (12.6.2017).

PETERSON, T. C., ZHANG, X., BRUNET-INDIA, M., LUIS VÁZQUEZ-AGUIRRE, J. (2008): Changes in North American Extremes Derived from Daily Weather Data. Journal of Geophysical Research: Atmospheres, 113, D07113.

RUML, M., GREGORIĆ, E., VUJADINOVIĆ, M., RADOVANOVIĆ, S., MATOVIĆ, G., VUKOVIĆ, A., POČUČA, V., STOJIČIĆ, D.J. (2017): Observed Changes of Temperature Extremes in Serbia over the Period 1961-2010. Atmospheric Research, 183, 26-41.

RUSSO, S., SILLMANN, J., FISCHER E.M. (2015): Top Ten European Heat Waves since 1950 and Their Occurrence in the Coming Decades. Environmental Research Letters, 10, 12, 124003.

RUST, H.W., RICHLING, A., BISSOLLI, P., ULBRICH, U. (2015): Linking Teleconnection Patterns to European Temperature - A Multiple Linear Regression Model. Meteorologische Zeitschrift, 24, 4, 411-423.

SKANSI, M.M., BRUNET, M., SIGRO, J., AGUILAR, E., GROENING, J.A.A., BENTANCUR, O.J., CASTELLON GEIER, Y.R., CORREA AMAYA, R.I., JACOME, H., MALHEIROS RAMOS, A., ORIA ROJAS, C., PASTEN, A.M., MITRO, S.S., VILLAROEL JIMENEZ, C., MARTINEZ, R., ALEXANDER, L.V., JONES, P.D. (2013): Warming and Wetting Signals Emerging from Analysis of Changes in Climate Extreme Indices over South America. Global and Planetary Change, 100, 295-307.

TRBIĆ, G. (2010): Ecoclimatological Regionalisation of the Peripannonian Rim in the Republic of Srpska, Geographic society of the Republic of Srpska, Banjaluka.

TRBIĆ, G., POPOV, T., GNJATO, S. (2017): Analysis of Air Temperature Trends in Bosnia and Herzegovina. Geographica Pannonica, 21, 2, 68-84.

UNKAŠEVIĆ, M., TOŠIĆ, I. (2015): Seasonal Analysis of Cold and Heat Waves in Serbia during the Period 1949-2012. Theoretical and Applied Climatology, 120, 1, 29-40.

UNKAŠEVIĆ, M., TOŠIĆ, I. (2013): Trends in Temperature Indices over Serbia: Relationships to Large-Scale Circulation Patterns. International Journal of Climatology, 33, 15, 3152-3161.

WANG, G., YAN, D., HE, X., LIU, S., ZHANG, C., XING, Z., KAN, G., QIN, T., REN, M., LI, H. (2018): Trends in Extreme Temperature Indices in Huang-Huai-Hai River Basin of China during 1961-2014. Theoretical and Applied Climatology, 134, 1-2, 51-65. 
ZHANG, X., YANG, F. (2004): RClimDex (1.0) User Manual. Climate Research Branch Environment Canada, Downsview, Canada.

ZWIERS, F.W., ZHANG, X., FENG, Y. (2011): Anthropogenic Influence on Long Return Period Daily Temperature Extremes at Regional Scales. Journal of Climate, 24, 3, 881-892. 